\title{
HUBUNGAN BERAT BADAN LAHIR RENDAH TERHADAP FREKUENSI KEJADIAN ISPA PADA BALITA USIA 1-4 TAHUN
}

\author{
Pertiwi Febriana Chandrawati ${ }^{\star}$, Farha ni Alhabsyi ${ }^{\star *}$
}

\begin{abstract}
ABSTRAK
Latar Belakang: Sebagian besar hasil penelitian di negara berkembang menunjukkan bahwa

$20-35 \%$ kematian bayi dan anak. balita disebabkan ISPA. Di Indonesia, ISPA merupakan masalah kesehatan masyarakat terutama terjadi pada bayi (0-11 bulan) dan balita (1-4 tabun). Diperkirakan kejadian ISPA pada balita di Indonesia sebesar 10-20\%. Faketor penyebab ISPA pada balita adalah berat badan labir rendah (BBLR), status gizi buruk, imunisasi yang tidak lengkap, kepadatan tempat tinggal dan lingkungan fisik.

Tujuan: Mengetahui bubungan berat badan labir rendah terbadap frekuensi kejadian ISPA pada balita usia 1-4 tahun.

Metode: Penelitian ini bersifat analitik observasional, dengan pendekatan secara Case control study. Pengambilan sampel dengan tekhnik purposive sampling. Dilakukan di wilayah kerja Puskesmas Kendal Kerep-Malang. Subyek penelitian mengisi 2 kuesioner, kuesioner pertama untuk menentukan kelompok kasus(sering ISPA) dan kelompok kontrol (tidak sering ISPA). Kuesioner kedua untuk mengetabui berat badan labir subyek dan faktor resiko berat badan labir rendah. Dianalisa dengan pearson correlation, odd rasio, dan uji Chi-square.

Hasil Penelitian: Penelitian ini mengikutsertakan 46 subyek. (23 sebagai kasus dan 23 sebagai kontrol). Responden yang termasuk. dalam kategori berat badan labir normal dengan kriteria kejadian ISPA tidak sering sebanyak 18 orang (39,1\%), sedangkan yang termasuk kriteria kejadian ISPA sering sebanyak 9 orang (19,6\%). Subyek yang termasuk dalam kategori berat badan labir rendah dengan kriteria kejadian ISPA tidak sering sebanyak 5 orang (10,9\%), sedangkan yang termasuk kriteria kejadian ISPA sering sebanyak 14 orang (30,4\%)., dengan nilai $r$ sebesar 0,839 dan OR $=5,60\{95 \%$ CI: $(\mathbf{1}, \mathbf{5 4}-\mathbf{6 , 6 6 )}\}$
\end{abstract}

Kesimpulan: BBLR diprediksi merupakan salah satu penyebab seringnya kejadian ISPA pada anak usia 1-4 tahun. Dengan resiko sebesar 6 kali dibanding pada bayi yang tidak. BBLC. Sehingga diharapkan bagi masyarakat agar waspada terhadap faktor-faktor yang dapat menyebabkan resiko melabirkan bayi dengan BBLR

Kata Kunci: BBLR, ISPA, Balita 1-4 tahun

\footnotetext{
* Bagian Ilmu Kesehatan Anak, Fakultas Kedokteran Universitas Mubammadiyah Malang.
} 


\section{ABSTRACT}

Background : most of research in developing country shows that mortality about 20-35\% of baby and children is caused acute respiratory infection (ARI). In Indonesia, ARI is a community bealth problem especially occurs to baby (0-11 month) and toddlers (1-4 years old). It is forecast that ARI problem to children in indonesia is 10-20\%. The risk factors caused ARI to children are low birth weight (LBW), malnutrition status, incomplete immunization program, population density and physical environment.

Objective : To determine the association between $L B W$ and the frequency of $A R I$ among children 1-4 years old.

Methods: Analytical observation research by using case control study approach. Process of sampling is using purposive sampling technique. This research was Conducted in a public health center at Kendal Kerep-Malang. The research subject is completing 2 questioner, first is to determine case group (frequent ARI) and control group (infrequent ARI). Second questioner is to know the birth weight of subject and the risk factor of $\mathrm{LBW}$. Analyzed by pearson correlation, odd ratio, and chi-square test.

Results : 46 subjects were studied (23 as case and 23 as control). Subjects which in normal birth weight criteria have 18 persons (39.1\%) with infrequent of $A R I$, and subjects which frequent ARI are 9 persons (19.6\%). Subject which in $L B W$ with the infrequent ARI are 5 persons (10,9\%), and which of frequent $A R I$ are 14 person (30.4\%), with $r$ value of 0.839 and $\mathrm{OR}=5.60\{95 \%$ CI: $(1.54-$ 6.66)\}

Conclusion : $L B W$ is predicted as one of the cause of the frequent ARI to children 1-4 years old. With potential risk of 6 times bigger compares to baby with no LBW. This is suggested to the community to be precautious to factors that can cause the risk factors of $L B W$.

keywords: $L B W, A R I$, children $1-4$ years old.

\section{PENDAHULUAN}

ISPA menyebabkan $40 \%$ dari kematian anak usia 1 bulan sampai 4 tahun. Hal ini berarti dari seluruh jumlah anak umur 1 bulan sampai 4 tahun yang meninggal, lebih dari sepertiganya meninggal karena ISPA atau diantara 10 kematian 4 diantaranya meninggal disebabkan oleh ISPA. Di Indonesia, ISPA masih merupakan salah satu masalah kesehatan masyarakat yang utama terutama pada bayi (0-11 bulan) dan balita (1-4 tahun). Diperkirakan kejadian ISPA pada balita di Indonesia yaitu sebesar 10$20 \%{ }^{1,2}$

Beberapa faktor yang mempengaruhi kejadian penyakit ISPA baik secara langsung maupun tidak langsung. Faktor risiko yang menyebabkan ISPA pada balita adalah sosio-ekonomi (pendapatan, perumahan, pendidikan orang tua), status gizi, tingkat pengetahuan ibu dan faktor lingkungan (kualitas udara). ${ }^{3}$ Sedangkan Depkes,2002 menyebutkan bahwa faktor penyebab ISPA pada balita adalah berat badan lahir rendah (BBLR), status gizi buruk, imunisasi yang tidak lengkap, kepadatan tempat tinggal dan lingkungan fisik. ${ }^{2}$ Meta-analisis menunjukkan bahwa BBLR mempunyai RR (Risk Ratio) kematian 6,4 artinya kejadian ISPA pada anak dengan BBLR 6,4 kali lebih sering dibanding pada anak yang tidak BBLR.
Data dari Dinas Kesehatan Kota Malang menunjukkan bahwa kejadian ISPA pada balita di kota Malang pada periode 1 Januari - 31 Desember 2009 masih sangat tinggi. Dari data tersebut didapatkan bahwa kasus di wilayah Puskesmas Kendal Kerep menduduki peringkat pertama sebesar 9,03\%. ${ }^{4}$ Oleh sebab itu peneliti memilih Puskesmas Kendal Kerep sebagai lokasi untuk meneliti hubungan berat badan lahir rendah terhadap frekuensi kejadian ISPA pada balita usia 1-4 tahun, mengingat angka kejadian ISPA di wilayah tersebut secara presentasi paling tinggi.

\section{METODE}

Penelitian ini bersifat analitik observasional, dengan pendekatan secara Case control study. Pengambilan sampel dengan tekhnik purposive sampling. Dilakukan di wilayah kerja Puskesmas Kendal Kerep-Malang. Subyek penelitian mengisi 2 kuesioner, kuesioner pertama untuk menentukan kelompok kasus(sering ISPA) sebanyak 23 subyek dan kelompok kontrol (tidak sering ISPA) sebesar 23 subyek. Kuesioner kedua untuk mengetahui berat badan lahir subyek dan faktor resiko berat badan lahir rendah. Kriteria inklusi untuk kelompok kasus adalah balita usia 1-4 tahun yang datang ke posyandu di wilayah kerja Puskesmas Kendal-Kerep Malang periode 1 Januari - 31 Desember 2009, 


\section{Hubungan berat badan lahir rendah terhadap frekuensi kejadian Ispa 33}

sering menderita ISPA dan orangtua menyetujui informed consent. Kriteria ekslusinya adalah yang mempunyai kelainan anatomis bawaan dan malignansi yang mempengaruhi fungsi respirasi. Kriteria inklusi pada kelompok kontrol adalah balita usia 1-4 tahun yang tidak sering menderita ISPA.

Frekuensi serangan ISPA dikategorikan atas tidak sering $(<7$ kali pertahun) dan sering $(>7$ kali pertahun). Episode baru berdasarkan laporan rekam medis dan berdasarkan pertanyaan quesioner 1 . BBLR adalah bayi baru lahir dengan berat kurang dari 2500 gram.

Data yang telah terkumpul dari kuesioner pertama dan kedua dianalisa dengan menggunakan pearson correlation, odd rasio, dan uji Chi-square.

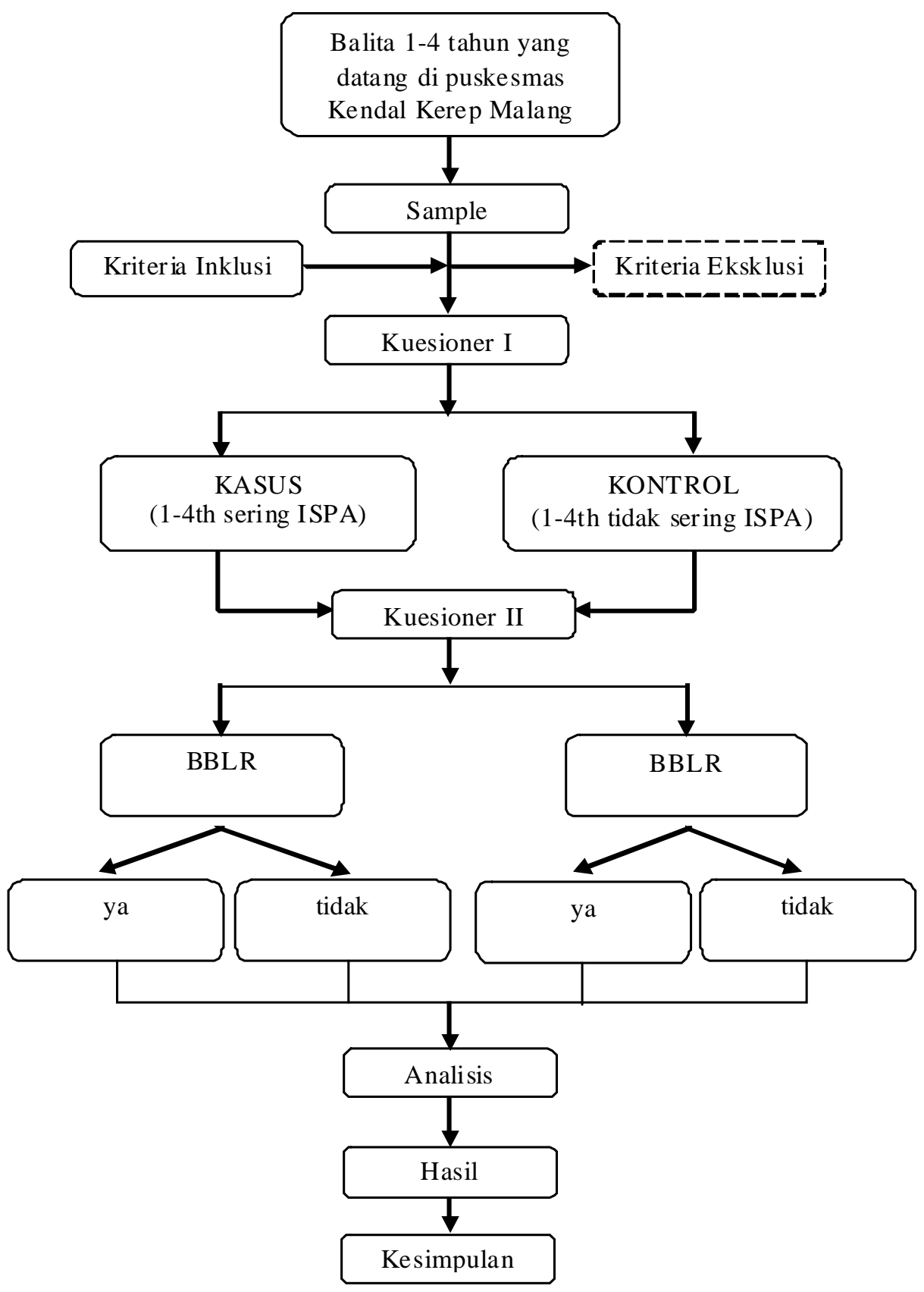

Gambar 1. Algoritma subyek penelitian 


\section{HASIL}

Berdasarkan hasil observasi untuk memberikan gambaran secara umum mengenai faktor-faktor yang mempengaruhi hubungan BBLR terhadap frekuensi kejadian ISPA pada balita 1-4 tahun di Puskesmas Kendal Kerep Malang di peroleh informasi mengenai data umum yang meliputi umur ibu,umur anak, pendidikan dan pekerjaan sedangkan data khusus meliputi berat badan lahir dan frekuensi kejadian ISPA. Jumlah total sample 46 subyek terbagi dalam kelompok kasus (sering ISPA) 23 subyek dan kelompok kontrol (tidak sering ISPA) 23 subyek (Tabel 1)

Tabel 1. Karakteristik data dasar $(\mathrm{n}=46)$

\begin{tabular}{|c|c|c|c|c|c|}
\hline Karakte ri stik & $\begin{array}{c}\text { Kasus } \\
\text { (sering ISPA) } \\
\mathrm{n}=23(\%)\end{array}$ & & $\begin{array}{c}\text { Kontrol } \\
\text { (tidak se ring } \\
\text { ISPA) } \\
n=23(\%)\end{array}$ & & $\mathrm{p}$ \\
\hline \multicolumn{6}{|l|}{ Umur ibu } \\
\hline$<20$ tahun & 9 & $(19,6)$ & 2 & $(4,3)$ & \multirow[t]{3}{*}{0,002} \\
\hline 20-35 tahun & 5 & $(10,9)$ & 17 & (37) & \\
\hline$>35$ tahun & 9 & $(19,6)$ & 4 & $(8,7)$ & \\
\hline Umur anak & & & & & \multirow[t]{7}{*}{0,000} \\
\hline $1-1,5$ tahun & 11 & $(23,9)$ & 2 & $(4,3)$ & \\
\hline $1,6-2$ tahun & 0 & (0) & 0 & (0) & \\
\hline $2,1-2,5$ tahun & 10 & $(21,7)$ & 0 & (0) & \\
\hline $2,6-3$ tahun & 0 & (0) & 0 & (0) & \\
\hline $3,1-3,5$ tahun & 2 & $(4,3)$ & 9 & $(19,6)$ & \\
\hline $3,6-4$ tahun & 0 & (0) & 12 & $(26,1)$ & \\
\hline Pendidikan & & & & & \multirow[t]{5}{*}{0,435} \\
\hline Tidak sekolah & 2 & $(4,3)$ & 1 & $(2,2)$ & \\
\hline SD & 8 & $(17,4)$ & 4 & $(8,7)$ & \\
\hline SMP & 7 & $(15,2)$ & 8 & $(17,4)$ & \\
\hline SMA & 6 & (13) & 10 & $(21,7)$ & \\
\hline Pekerjaan & & & & & \multirow[t]{5}{*}{0,030} \\
\hline IRT & 14 & $(30,4)$ & 14 & $(30,4)$ & \\
\hline Petani & 0 & (0) & 5 & $(10,9)$ & \\
\hline Wiraswasta & 8 & $(17,4)$ & 2 & $(4,3)$ & \\
\hline PNS & 1 & $(2,2)$ & 2 & $(4,3)$ & \\
\hline Berat Lahir Saat & & & & & \multirow[t]{4}{*}{0,007} \\
\hline Bayi & & & & & \\
\hline $\begin{array}{l}\text { Tidak Rendah } \\
\text { (BBLC/BBLB) }\end{array}$ & 9 & $(19,6)$ & 18 & $(39,1)$ & \\
\hline Rendah & 14 & $(30,4)$ & 5 & $(10,9)$ & \\
\hline
\end{tabular}

Secara statistik variabel bebas yang bermakna terhadap frekuensi kejadian ISPA adalah umur ibu, umur anak, pekerjaan dan berat badan lahir, 
Tabel 2. Analisis bivariat faktor resiko yang mempengaruhi frekuensi ISPA

\begin{tabular}{l|c|cc}
\hline Faktor resiko & $\mathbf{p}$ & $\mathbf{O R}$ & $\mathbf{9 5 \%} \mathbf{C I}$ \\
\hline Umur ibu & 0,002 & 0,89 & $0,79-0,98$ \\
Umur anak & 0,000 & 1,05 & $0,86-1,29$ \\
\hline Pekerjaan & 0,030 & 0,98 & $0,75-1,1$ \\
\hline BBLR & 0,007 & 5,60 & $1,54-6,66$
\end{tabular}

Dari data di tabel 2 melalui analisis regresi logistik dapatlah dilihat faktor resiko yang berpengaruh terhadap seringnya frekuensi ISPA adalah umur ibu (OR 0,89 95\% CI: 0,79 - 0,98) dan BBLR (OR 5,60 95\% CI : $1,54-6,66)$

\section{PEMBAHASAN}

Berdasarkan hasil penelitian dengan menggunakan kuesioner kepada ibu balita usia 1-4 tahun yang datang ke Puskesmas Kendal KerepMalang periode 1 Januari - 31 Desember 2009 didapatkan bahwa sebagian besar pada kelompok kontrol berat badan lahir responden termasuk dalam kategori normal sebanyak 18 orang $(39,1 \%)$ sedangkan pada kelompok kasus berat badan lahir responden termasuk dalam kategori rendah sebanyak 14 orang $(30,4 \%)$.

Subyek yang termasuk dalam kategori berat badan lahir rendah dengan kriteria ISPA tidak sering terdapat sebanyak 5 orang $(10,9 \%)$, sedangkan yang termasuk kriteria kejadian ISPA sering terdapat sebanyak 14 orang (30,4\%). Analisa data yang digunakan adalah uji korelasi Pearson. Pada uji korelasi Pearson pada penelitian ini didapatkan nilai kekuatan korelasi (r) sebesar 0,839 yang meyatakan derajat korelasi antara berat badan lahir rendah dengan frekuensi kejadian ISPA adalah dikategorikan sangat kuat. Berarti BBLR merupakan salah satu faktor yang berpengaruh terhadap frekuensi kejadian ISPA pada balita usia 1-4 tahun.

Sehingga dari hasil penelitian ini dapat disimpulkan bahwa terdapat hubungan BBLR terhadap frekuensi kejadian ISPA pada balita usia 1-4 tahun di puskesmas Kendal Kerep - Malang periode 1 Januari - 31 Desember 2009 dengan kekuatan sangat kuat. Walaupun masih ada faktor resiko lain dapat diperhitungkan yang menyebabkan frekuensi kejadian ISPA.

Dari hasil perhitungan nilai OR 5,60 \{95\% CI: $(1,54$ - 6,66) $\}$, masih berada dalam rentang nilai atas dan bawah, maka estimasi yang menyatakan bahwa ada asosiasi positif antara berat badan lahir rendah dengan frekuensi kejadian ISPA. Sehingga dapat disimpulkan ISPA dengan frekuensi sering pada anak dengan berat badan lahir rendah 6 kali lebih frekuen dibanding pada anak dengan berat badan lahir normal. Secara statistik signifikan dapat diterima dan dipertanggung jawabkan.

Beart badan lahir menentukan tumbuhkembang fisik dan mental pada masa balita. BBLR mempunyai resiko kematian yang lebih besar dibandingkan BBLC, terutama pada bulan-bulan pertama kelahiran, karena pembentukan zat anti kekebalan yang kurang sempurna sehingga lebih mudah terkena penyakit infeksi, terutama pneumonia dan penyakit saluran pernafasan lainnya. Bayi dgn BBLR sering mengalami gangguan pernafasan. Hal ini disebabkan oleh pertumbuhan dan perkembangan paru yang belum sempurna dan otot pernafasan yang masih lemah. ${ }^{5,6}$

Adanya infeksi virus merupakan predisposisi terjadinya sekunder infeksi. Sebenarnya infeksi virus bersifat self_limiting disease, tetapi karena bayi BBLR memiliki sistem pertahanan tubuh yang rendah terhadap mikroorganisme pathogen, denagn infeksi ringan saja sudah cukup membuat sakit, 
sehingga bayi BBLR rentan terhadap penyakit terutama penyakit ISPA.

Akibat infeksi virus tersebut terjadi kerusakan mekanisme mukosiliaris yang merupakan mekanisme perlindungan pada saluran pernafasan terhadap infeksi bakteri sehingga memudahkan bakteri-bakteri pathogen yang terdapat pada saluran pernafasan atas seperti streptococcus pneumonia, haemophylus influenza dan staphylococcus menyerang mukosa yang rusak tersebut. ${ }^{7}$

Dampak infeksi sekunder bakteri pun menyerang saluran pernafasan bawah, sehingga bakteri-bakteri yang biasanya hanya ditemukan dalam saluran pernafasan atas, sesudah terjadi infeksi virus dapat menginfeksi paru-paru sehingga menyebabkan pneumonia bakteri. ${ }^{6,8}$

Peneliti memiliki keterbatasan yang dapat dijadikan acuan untuk penelitian di masa mendatang terkait dengan berat badan lahir rendah (BBLR) dan ISPA pada balita, yaitu : peneliti hanya membahas salah satu faktor yang mempengaruhi frekuensi kejadian ISPA yaitu berat badan lahir rendah (BBLR), tidak membahas faktor-faktor lain yang mempengaruhi frekuensi kejadian ISPA seperti jenis kelamin, status gizi, pemberian ASI, imunisasi, dan status sosial ekonomi.

\section{DAFTAR PUSTAKA}

Departemen Kesehatan Republik Indonesia. Pedoman Pemberantasan Penyakit Infeksi Saluran Pernafasan Akut untuk Penanggulangan Pnemonia pada Balita. Jakarta, $2000: 4-20$.

Depkes R.I., (2002) Pedoman Pemberantasan Penyakit Infeksi Saluran Pernafasan Akut Untuk Penanggulangan Pneumonia Pada Balita, Ditjen PPM-PLP. Jakarta

Dharmage SC, Chandrika R, Lalani F, Dulitha N. Risk Factors of Acute Lower Respiratory Tract Infections in Children Under Five Years of Age. Southeast Asian Journal of Trop.Med Public Health. 27 (1). 1996. p : $107-110$.

ISPA Ancam Kota Malang. Cyber Media. 2007. http://www.kompas.com/verl/Kesehatan/ $0711 / 01$.

Saifudin AB, dan Rachimhadhi T. Bayi Dengan Berat Lahir Rendah. Dalam : Ilmu Kebidanan. Yayasan Bina Pustaka Sarwono Prawirohardjo. Edisi III. Cet. 5. Jakarta. 1999 : 771 - 790

Baqui A. Some Low Birth Weight Infant Destined to be Small to Life. March, 1 2001. http:/ Lwww.jhsph.edu/publichealth.

Raymond WR, Deane WC and Hack M. Placental and Other Perinatologi Risk Factors for Chronic Lung Disease in Very Low Birth Weight Infants. Internasional Pediatric Research Foundation Inc Vol 52, No 5, 2002:713-714

Kristensen JA, Community Study of Acute Respiratory Infection in Children Less than One year of Age. 2004. http:// www.danmedbul.ah/DMB.2004. 